\title{
Por três anos, Até 1955... (*)
}

\author{
Basileu Garcia \\ Catedrático de Direito Penal na Faculdade \\ de Direito da Universidade de São Paulo.
}

Por três anos, até 1955, prezados bacharelandos, fui vosso professor. Éreis, aproximadamente, trezentos rostos jovens e simpáticos, com aquela proverbial irrequietude da mocidade. Mas, ou eu muito me enganava, ou os vossos olhos e ouvidos estavam realmente atentos às preleções de Direito Penal, disciplina cujos aspectos humanos pareceram desde logo despertar a vossa curiosidade.

Há, no estudo dêsse ramo da ciência jurídica, algo de épico e comovente, na efervescência das idéias liberais e suas reivindicações audazes, após a longa f́ase de trevas efm que andaram mergulhadas as comunidades oprimidas. $\mathrm{Na}$ trincheira das instituições penais travaram-se as mais fecundas batalhas pela liberdade. As reformas estruturais que marcaram o seu campo no passado foram conquistas contra o arbitrio. Por certo, havieis de vibrar na rememoração das vicissitudes agoniadas por que passou a humanidade até que se suplantassem os desvarios do poder para chegar-se ao equilíbrio dos interêsses individuais e sociais na repressão ao delito.

No exercício do magistério, não me mantive distanciado de vós. De modo geral, tomastes parte ativa nas aulas, com as vossas constantes interpelações, que sempre admiti e mesmo incrementei, convencido de que essa animada interferência vos convidava ao raciocínio. A atenção ne-

(*) Discurso de paraninfo à turma de bacharéis de 1956. 
cessita ser cultivada. Arrisca-se a monologar, sem ouvintes, embora numa sala repleta, o expositor que de quando em quando não espicaça a atenção por algum método que modifique o terra-à-terra do panorama e sacuda as inteligências sufocadas pela monotonia e pelo cansaço. Eis porque eu tantas vêzes vos envolvi nas explanações, provocando a vossa intervenção e respondendo com solicitude às vossas perguntas, fôssem muito cabíveis ou pouco, sem jamais declará-las impertinentes ou de outra maneira menosprezá-las.

Procurei conviver convosco, sondando-vos e colocando-me ao vosso lado sem barreiras difíceis. Assim, tornámo-nos bons amigos, a tal ponto que de muitos de vós colhi, não raro, palavras absolutamente francas de crítica, o que tenho como a expressão mais alta da cordialidade nas relações entre o mestre e os seus discípulos. Quando, a despeito dos nossos complicados ritos universitários, o aluno não se constrange em comunicar ao professor o que pensa, nem vislumbra nisso uma fantástica demonstração de petulância capaz de estarrecer os colegas, e o faz com desataviada lealdade, é porque o destinatário das suas revelações lhe inspira confiança. E inspirá-la constitui legítima recomendação à estima. Inspira-nos confiança aquêle com quem sabemos poder contar, aquêle que tem boa vontade em nos ouvir e se mostra propenso a nos valer de alguma coisa. Porque cuidei de angariar a vossa confiança, elegestes-me paraninfo.

Já o hiato de um ano se interpusera entre a nossa despedida e a vossa gènerosa escolha, tempo mais que bastante para me banirdes de tôda recordação. Entretanto, fostes buscar-me no recolhimento da minha existência obscura para me conferirdes a honraria insigne que neste momento desfruto e que, a meu ver, é a maior a que pode ser alçado um professor.

Nem por um momento subestimei o vosso gesto. Na quadra em que me encontro, os desenganos foram tantos, as amarguras tamanhas, que o ceticismo já me congelou, 
inevitàvelmente, largo trecho da alma. É fraca, então, a receptividade às seduções e aos deslumbramentos. Bruxoleia a chama dos antigos entusiasmos. $O$ aguilhão da vaidade, que é um dos estímulos mais agudos da criatura neste vale de lágrimas, acha-se enfraquecido, quase extinto. Passado o cabo da boa esperança, já não existem postos a pretender, dignidades a almejar, láureas a ambicionar. Todavia, é verdadeiramente encantadora esta com que me galardoastes: ser o vosso paraninfo.

Confesso espontâneamente, sem subterfúgios, que a eleição com que me distinguistes me comoveu e sensibilizou e continua a comover-me e a sensibilizar-me como nada me comoveu e sensibilizou tanto até hoje. O professor que recebe semelhante prêmio renova as suas energias. Vê-se compreendido e apoiado; julgado, pelas suas ações e omissões, pelo pouco que fêz e pelo muito que deixou de fazer. $\mathrm{E}$ absolvido. Note-se que não há julgador mais inflexível do que o estudante, em face de quem o obriga a estudar.

A emoção explica a tartamudice dos meus primeiros agradecimentos, naquela noite chuvosa em que fostes surpreender-me sob as ruinas da minha residência em reforma. Éreis tantos, e o espaço habitável era tão exíguo! Extravasastes-vos ao relento, sob os respingos do intermitente aguaceiro. $O$ alarido inesperado com que surgistes acordou em sobressalto o quarteirão modorrento, mas a tranquilidade se restaurou ante o tom característico das vossas manifestações, em que sempre se entrecruzam o soturno dos quim-quinquéros e a alacridade estrepitosa do foguetório final. Que é que pude enunciar-vos, em seguimento à cintilante saudação do vosso orador? Lembrai-vos de que falei pouco e falei mal.

Não vos iludais, porém, quanto ao significado daquelas expressões breves e chãs. É o mesmo sentido destas outras, amadurecidas na solidão de um gabinete, no silêncio de quatro paredes. É o mesmo e um só: com poucas ou com muitas explicações, nos solavancos do improviso ou lendo o que foi meditado, o fato íntimo que os vocábulos 
querem exprimir, e nunca exprimirão suficientemente, é a minha gratidão aos estudantes que me convocaram para os apadrinhar neste ato solene.

Convém que vos esclareça como entendo os laços do paraninfado. Não os tenho por frouxos ou fugazes, e sim por estáveis e eternos, ad vitam. Indissolúveis como os do matrimônio segundo a nossa Constituição. Sou, pois, como o convidado que vai ao vosso domicilio e não quer mais retornar ao seu. Inútil seria que bocejásseis, sob educado disfarce, a vossa mal contida impaciência ante o prolongamento enfadonho da visita. O hóspede, ultra-convencido do seu dever de cortesia, obstina-se, firme, na poltrona em que o instalaram, e não se despede tão cedo. Anàlogamente a êsse hóspede, estarei convosco muito mais do que podeis supor, observando a vossa sorte, para o aplauso oportuno ou para confortar-vos nos instantes de desalento.

Paraninfo, assim penso, não é para algumas horas, e sim para muitos anos.

Através dêle, no caso particular da nossa Faculdade, deve perpetuar-se a vossa ligação com esta Casa, da qual saís materialmente, mas da qual jamais deveis afastar-vos espiritualmente. Em suma, o paraninfo é, dentre os professôres, o que designastes para ser o vosso cônsul aqui dentro e para continuar a ser, lá fora, o vosso guia e coadjuvante devotado, após a conclusão do curso jurídico.

Nele deveis entrever o colega mais idoso, cujo conselho invocareis nas graves conjunturas de aflição e desespêro, das vacilações atrozes que roem as nossas fibras profundas e instam pelo socôrro amistoso de alguém que nos fale uma linguagem sem preconceito. Ah! quantos de nós deploramos não haver contado, em certas ocasiões, principalmente nos primeiros tropeços, com uma voz que se fizesse escutar sem o intuito de nos ser agradável, mas pretendendo exclusivamente que descortinássemos a razão e a verdade! A muitos erros nos teríamos subtraído, a muitos dissabores cruéis nos teríamos poupado. 
Estais apenas para inaugurar a liça que o término do vosso aprendizado propicia e aqui me achais a falar-vos em perspectivas tristes, em que a angústia e o desânimo se apoderam de nós. Escusai-me: é que não desejo esquivar-me à realidade. Qualquer que seja o caminho que escolherdes, a partir da encruzilhada múltipla em que hoje vos encontrais, tereis, antes das vitórias que vos esperam, muito que penar, e é bom que estejais prevenidos para os reveses que defrontareis.

Sereis, provàvelmente, advogados militantes. Para as hostes da advocacia vaí o maior número dos nossos bacharéis. Como é bela, mas como é também inclemente, a advocacia! Voltaire lamentou não ter podido exercê-la, mas Napoleão exteriorizou a sério o prazer com que cortaria a língua aos causídicos que incomodavam o Estado todo-poderoso.

Os atrativos da profissão não impedem que ela constitua um pródigo manancial de sofrimentos. Para ser advogado, é preciso trabalhar ininterruptamente. Ilusórios e precários são os ócios do profissional dos prélios forenses. A sua pobre cabeça sobrecarregada não conhece o repouso. A preocupação, que o não larga, acha-se voltada para os autosi de que lhe abriram ou logo lhe abrirão vista, para o "dossier" que necessita ser revisto e completado, para as provas que terá ainda de coligir, para o arrazoado que delineará de modo a impressionar, a fim de vencer.

Os seus conhecimentos nunca lhe bastam. Há que aprimorá-los dia a dia, lendo e relendo velhas obras, compulsando os escritos doutrinários que surgem, seguindo a volúvel jurisprudência dos tribunais, sistematizando os seus apontamentos, ordenando e acrescendo diuturnamente. o arquivo que auxiliará a sua memória.

O que sobretudo desgasta o advogado é a sua identificação com os paroxismos do cliente, sem o que será manco e improfícuo o desempenho do mister. Advogado, merecedor dêsse nome, é o que patrocina a causa, que lhe foi entregue, como se fôsse a sua própria. Será só? Não; é 
bem mais: que defende a causa do cliente como não defenderia a sua própria causa; que coloca acima dos seus. próprios bens os que se acham sob a sua vigilância de mandatário.

Direis que isso é paixão e que o homem sensato deve evitar apaixonar-se. Excetuem-se, contudo, as absorventes. tarefas da advocacia, porque advogado frio, de nervos de aço, simples espectador, e não ator, dos dramas que se desenrolam à sua frente, não é bem um advogado, estando mesmo a fazer falta no dicionário uma designação que the sirva.

A renovação interminável do estudo, um cuidado sem quartel com os assuntos a serem discutidos, um afã estenuante que tomará todo o vosso tempo, eis o que vos aguarda nessa formosa profissão, se a aceitardes em tôda a sua mortificadora efetividade; se quiserdes ser advogados e não diletantes da advocacia.

$\mathrm{E}$ quais as compensações? Renome, a reverência, o êxtase da turba? Não acrediteis nessas divindades efêmeras. Fortuna, estabilidade econômica? Poucos a conseguem, e jamais é parecida com a que, com facilidade infinitamente maior, se aufere em empresas para as quais não se requer nenhum aprimoramento especial das faculdades. psíquicas.

Em realidade, o consôlo do advogado que se esfalfa nem é a fama, nem é, em geral, a prosperidade e abastança. E a satisfação da sua própria consciência. Traz-nos alguma felicidade a certeza de que ocupamos com eficácia o setor que o destino nos reservou e de que estamos amparando com diligência providencial os que se acercam de nós nas horas mais cruciantes. Nem é tributo secundário a grata aprovação que, tantas vêzes, deparamos pelo camiminho. Advogar é pelejar, altruìsticamente, pelo direito alheio, e o direito é o travejamento da estrutura social. Operário da imensa construção, o advogado erguerá uma. coluna mestra se trabalhar com esfôrço. 
Não é preciso, para que seja eficiente a participação do obreiro, que os fados the hajam concedido uma lucidez além da comum e que a sua habilidade se compare à do prestidigitador que acha coelhos, flores e bandeiras no fundo de uma cartola vazia. Sem sortilégios, e mesmo na mediania da inteligência, poderá ser notável advogado aquêle que tiver ânimo forte, fôr perserverante, resistente à fadiga, aos padecimentos morais e sentir decidido gôsto pelo aperfeiçoamento técnico e cultural.

Há quem pense que para advogar é necessário ser um engenhoso inventor de frases bonitas, e logo desanimará ante a incapacidade, em que se percebe, de arrumar algumas proposições sonoras e pomposas. Ledo e cego engano! Não se enleará em dificuldade invencível no falar ou escrever quem tiver um assunto para expor. Não emudecerá na tribuna ou na estacada do revide no processo o defensor persuadido da razão do seu constituinte. Não lhe faltará o argumento convincente se a sua demanda for justa. Se não o fôr, absfenha-se de aceitá-la, e deixe que algum dos mágicos, que por aí existem, inúmeros, a tome a si e a defenda.

O que mais chocará o observador desprevenido, nota, em relação aos tribunais franceses, Henri Robert, é o tom de simplicidade dos discursos. Recorda, a propósito, a apreciação singela,mas expressiva, emitida no auditório parisiense, quando um advogado assás conhecido pelo seu talento terminava uma das suas brilhantes orações: "Quem é? perguntou alguém da assistência, visivelmente entusiasmado. - Não o conhece? contravieram. Mas é maître Vutel! $\mathrm{Ah}$ ! replicou o interrogante incrédulo, é "maître" Vutel? Como fala com simplicidade!"

A emoção, fora de dúvida, comenta o conspícuo "bâtonnier", não foi cancelada da oratória forense, como o não foi da vida nem do coração humano. Mas deve ser uma emoção discreta e moderada, que se adivinhe e não pese, que se mostre só em certas inflexões, sem alarde. Nada mais falso do que o gênero teatral no fôro, nada que 
possa ser mais perigoso, porque nada nos dá menos a impressão de sinceridade. E consigna que quanto mais um advogado adquirir prática e quanto maior fôr a sua reputação, mais se empenhará em adaptar-se a êsse modêlo de croncisão e elegante simplicidade.

As mais melancólicas reflexões que já li sôbre o mourejar do advogado - melancólicas mas eđ̃ificantes pela austeridade com que a senda áspera do dever é indicada aos que se estreiam - foram enunciadas por um professor desta Casa, já quando estava próximo o fim dos seus dias. Em testemunho da autenticidade das suas declarações, frisou, com Quinault, que nada tem mais para dissimular quem não antevê senão alguns escassos momentos para viver. Com efeito, ao perpassar as reminiscências do Prof. João Arruda, advém-nos a impressão de que o advogado está sitiado numa cidadela, em que os ataques se lhe endereçam de tôdas as bandas, - dos clientes, dos serventuários, dos magistrados.. e também dos demais advogados. Envolve-o a perfídia de gregos e troianos, cavam-lhe a cada passo alçapões, colocam-lhe na trilha espinhos que the dilacerarão os pés.

Acompanhe-se êste lance pessimista: "O Código de Ética é tudo quanto há de menos útil. Constantemente se diz que é Moral fazermos aos outros o que quereríamos que êles nos fizessem. Mas, na guerra, do mesmo modo que no fôro, quem seguir êsse conselho está perdido. Na cruenta luta entre os homens, há as represálias, a retorsão, a retaliação e outras medidas não menos duras, autorizadas pelo Direito Internacional. No fôro também o único preceito é "fazer aos outros precisamente o que êles nos fazem". Proceder de modo diferente é um suicídio. Entre advogados, a menos que se trate de algum com pretensão a ser canonizado, reina a impiedade: mors tua vita mea".

Nos embates judiciários, para o emérito catedrático de Filosofia do Direito e advogado dos mais ilustres que já houve em São Paulo, os membros da nossa grei desmentem o aforismo de que "lobo não come lobo". Esquecido 
- exemplifica - de que nossos avós já haviam feito esta observação, entendeu Nansen, o grande explorador das regiões polares, premido pela escassez de mantimento, salvar os mais fortes de seus cães que puxavam os trenós da expedição, matando os mais fracos, para com esta carne salvar os reservados. Reconheceu logo, porém, que a medida foi inútil, porque os sobreviventes preferiam morrer de fome a comer o repugnante alimento que lhes era fornecido. Se a antropofagia - conclui, desconcertantemente - se acha tão disseminada, se os homens, quando não se atiram às carnes palpitantes ou moqueadas dos seus semelhantes, não recuam em apunhalar a reputação de seus irmãos, é de crer que, se os cães falassem, nunca difamariam seus companheiros, nem seguramente haveria um Dante da raça canina para celebrar um Ugolino perdigueiro".

Parece, por aí, que êsse satirizador impenitente levou longe demais a advertência de um outro comentador dos altos e baixos das refregas judiciárias, o jurista português Pinto Loureiro, para quem aquêle que intente discorrer sôbre as lides do fôro, só porque figure entre os iniciados, não pode ficar adstrito a uma benevolente parcialidade, senão cumplicidade, a qual seria idêntica à do monge que, redigindo a crônica do seu convento, elaborou um volume de mansa apologética.

Se a incredulidade alcançou no ocaso da existência a pena otogenária do nosso antigo mestre ao historiar os seus sessenta anos de vida forense, o escrito que nos legou representa, em muitas passagens, uma conclamação ardorosa, servindo para retemperar os indecisos e dar alento aos que começam. As apreciações são ferinas, as críticas são cáusticas, mas uma inferência confortadora se insinua em cada canto de página.

É exato que, armados cavaleiros para as pugnas da advocacia, tereis de investir contra o campo contrário, em que se acha, sempre, um igual a vós, outro advogado. Mas o que enobrece êsses combates é, exatamente, a sua lisura, a honestidade dos meios empregados em travá-los. Nunca 
vos diminuais imitando os que não se respeitam a si mesmos. Imprimi às vossas ações a compostura peculiar aos fortes. Usai de todos os vossos recursos, mas só os recursos lícitos, para destroçar a posição do adversário. Não o priveis, porém, da vossa operante solidariedade. Sobretudo, não cultiveis o rancor que o transforme em inimigo. Estendei-lhe a mão. Deplorai as ocasiões em que os excessos alheios torne isso impraticável.

Uma das mais tocantes virtudes da nossa coletividade universitária é o espírito de classe, o companheirismo. No dia em que não fordes amigos dos vossos condiscípulos, tereis deixado de morar idealmente nesta Casa, de que são filhos todos os que aqui viveram. Não vos olvideis de que a corporação dos advogados, embora afervorada nos dissídios que são o seu ambiente natural, necessita permanecer coesa, sem o que, corroída pela cisânia, não passará de um aglomerado heterogêneo, desprezível pela sua falta de expressão. Mantende-vos, pois, unidos, advogados! Principalmente, desejo que os meus afilhados se vinculem sempre na mesma fraternidade que aqui os reune numa comunhão de alegria.

Esta não vos pertence exclusivamente, e sim também às vossas famílias. Quantas contemplo, enchendo o salão nobre da Academia com o seu regosijo e com os votos de felicidade augurados aos entes estremecidos que afirmaram o seu triunfo na colação de grau! A festa de formatura, pelo eflúvio de enternecimento a que conduz, bem se parece com a de Natal. É como se fôra um Natal celebrado coletivamente, na unidade dos auspícios que elevam o pensamento a Deus e à Pátria. Partamos dêste congraçamento afetivo com inextinguíveis reservas de tolerância e compreensão.

A muitos de vós atrairá a magistratura. A êsses ditar-lhes-ão a preferência o horror pelas exterioridades, uma pronunciada inclinação para as soluções equânimes e uma coragem cívica inconsútil. Indiferente às censuras 
alheias, o juiz, assim como julga, julga-se, e há de obedecer apenas aos imperativos da sua ponderação serena. Não pode ser popular, já o avisou Teodor Sternberg no seu volume de Introdução à Ciência do Direito: ao aproximar-se dos homens para penetrar-lhes nos desígnios, pratica atos de redenção tão discreta, que os favorecidos pelo gládio salvador não sabem haverem inspirado simpatia.

A magistratura é um sacerdócio. Não terá genuína vocação para se incluir nos seus quadros quem não aquilatar em si a pureza de intenções que o arminho das vestes talares simboliza e que alimenta a fôrça moral, a mais poderosa de tôdas as fôrças, porquanto as armas sempre acabaram cedendo o seu passo à toga. Nem a terá quem nutrir aversão pelo gênero humano. Julgar sem doçura, ainda que com acêrto formal, não é praticar verdadeiramente justiça, a cujo conceito, por ensinamento do maior dos Mestres, o Divino Mestre, se associa a idéia de longanimidade.

É virtude ser juiz, merecendo a investidura. Não privemos, porém, dos nossos encômios os que a afastam de si por estar acima da sua aptidão. Há, portanto, duas maneiras de prestar bons serviços à magistratura: perfilhando-a e fugindo-lhe.

Aos que se destinarem ao Ministério Público, carreira a que me integrei durante uma inesquecivel década da minha recuada mocidade, louvo o pendor para uma das mais nobilitantes missões. Não vos arreceeis de ser o acusador oficial. Quem acusa defende. Defende as vítimas dos malefícios e os elevados e impessoais reclamos da coletividade, que há de ser preservada contra os virus que a enfermam e desagregam.

Aí também a paixão vos atingirá em cheio. É equívoco imaginar que seja menos empolgante a luta quando desencadeada em nome da sociedade do que quando se postulam, concretamente, pretensões de particulares. Guardo da Pro- 
motoria a recordação agitada de muitas noites de insônia e de muitas caimbras nervosas nas pernas após haver testemunhado dolorosas iniquidades. Não é nada maior o desgôsto, ao contemplá-las, agora, do outro lado da barricada.

Mas, se quiserdes ser não só operosos, mas sobretudo e redundantemente justos promotores de justiça, ocupai-vos antes em advogar. Igualmente o exercício da magistratura há de ser indeclinàvelmente precedido de não poucos anos de tirocínio livre-atirador na advocacia, que nos proporciona uma visão mais exata, menos deformada, dos horizontes jurídicos-sociais.

$\mathrm{E}$ quantos de vós ireis servir à Polícia civil paulista, corporação criada e dirigida por bacharéis, o que explica a sua capacidade de renovação com que trata de colocar-se à altura das conveniências da prevenção e da repressão da criminalidade?

Onde quer que estejais, irradiados em tôdas as direções, e ainda na administração e na política, conservai o espírito idealista que é o clima inalterável destas arcadas seculares, e, bem assim, o sentimento da sua glória imortal, de que são artífices as gerações de moços que por aqui transitam.

A nossa Escola, com a sua influência decisiva nos destinos da nacionalidade, tem escrito a história do Brasil, com a faina pacífica e também com o sangue heróico dos seus filhos. E continuará a escrevê-la, enquanto não soçobrar a consciência jurídica neste País.

Para que não soçobre, aí estais vós na estacada, já agora além dêstes muros.

São enormes as vossas responsabilidades. As mazelas que infelicitam a nossa Pátria, as deturpações do regime democrático, o êxito prodigioso dos maus, a miséria excessiva dos desprotegidos, vergonhosa para as elites, o tripúdio sôbre as ilusões dos humildes pelo acúmulo de desca- 
labros cada vez mais alarmantes, são derrotas infligidas ao espírito jurídico, ao Direito, que representamos, o qual é harmonia e disciplina.

"A relações entre os homens, desde muitos séculos, professa Georges Ripert em "Les forces créatices du droit", acham-se asseguradas pelo respeito às regras morais, entre as quais se incluem os deveres de justiça e caridade para com o próximo".

Mas, indago, numa época em que os representantes do povo, que deveriam ser os porta-vozes das aspirações legítimas, tripudiam sôbre as prerrogativas do Poder a que foram levados, tentando suprimir-lhe a liberdade de crítica, e dão o exemplo de insensibilidade ante o infortúnio dos pequeninos, satisfazendo preferencialmente os seus próprios apetites à custa dos depauperados orçamentos nacionais, e querem rodar em luxuosas limousines pela rua da amargura em que reside o desconfôrto dos seus representados, convenhamos em que a estrela do Direito empalidece em face do surto ofuscante da ilegalidade e da anarquia.

Oxalá não vos desencoraje, prezados bacharelandos, o reconhecimento, a proclamação dessas derrotas humilhantes! Se amais o Direito, batei-vos por êle sem desfalecimento, ainda mais nas conjunturas amargas de crise de caráter e de pudor. Fixai indelèvelmente na retina a lembrança dos corpos de colegas vossos ceifados nas vias públicas e nos campos de honra em nome da resistência viril que esta Faculdade sempre opôs aos desmandos de tôda espécie. $O$ seu aniquilamento, derrubados, mas não vencidos pela propotência, converteu-se numa sublime e perene lição para nós-outros.

Cumpra, pois, cada um o seu dever, e bênçãos recairão sôbre esta Casa, que depurou a vossa formação científica e tem igualmente de colaborar para a vossa formação moral. 
Tornar-vos-eis, dessa maneira, ativos cultores da seara jurídica e mestres de vossos mestres. A nossa imagem de modeladores da juventude estudantil reflete-se no espêlho das vossas mentes, mas nós, que vos encaminhamos, reagimos à semelhança dos impulsos que intimamente vos dominam. Se os frequentadores das nossas aulas não nos incentivassem com os seus feitos, seriam mofinos os frutos do labor que aqui pertinazmente se realiza. Assim, é certo que nos ensinais a ensinar!

Um princípio lançado em bom espírito germina, como a semente em terra propícia. Enriquece-se o espírito, mas também se rejubila o semeador, a quem aproveita o milagre da criação.

Aqui ficamos atentos ao que ireis fazer, meus queridos amigos, pela grandeza do Brasil. Que Deus vos ilumine! 